УДК 62 229. 316. 0002. 51

DOI https://doi.org/10.15673/swonaft.v85i1.2068

\title{
ІНЖЕНЕРНІ МЕТОДИ РОЗРАХУНКУ ПРОЦЕСУ ГІДРАТАЦЇ̈ ПРИ ОБРОБЦІ ОЛІЇ ЕЛЕКТРОМАГНІТНИМИ ХВИЛЯМИ
}

\author{
${ }^{1}$ Осадчук П. І., Д-р техн. наук, доцент, \\ ${ }^{2}$ Безбах І. В. д-р техн. наук, доцент \\ ${ }^{1}$ Одеський державний аграрний університет \\ ${ }^{2}$ Одеська національна академія харчових технологій
}

До основних недоліків стандартних ліній гідратаиії відносяться висока енергоємність, велика витрата холодної води і пари, що зв'язано з використанням сепараторів, а також жорстким температурними режимами сушіння фосфоліпідної емульсіі. Ці лінї не забезпечують ефективність процесу в иілому через високий залишковий зміст фосфоліпідів в олії і низької харчової иінності одержуваних фосфатидних концентратів унаслідок впливу перекису водню, застосовуваної для знебарвлення. Для усунення цих недоліків було запропоновано використання електромагнітних полів в процесі гідратації олій.

В даній роботі запропоновано інженерні методи розрахунку процесу гідратації при обробиі олії електромагнітними хвилями. Проведено моделювання прочесу.

Використовуючи метод аналізу розмірностей, отримано критеріальне рівняння для розрахунку продуктивності устаткування. Проведено узагальнення експериментальних даних отриманих в результаті досліджень.

Розроблено алгоритм розрахунку степеневих показників та констант в рівнянні у числах подібності, який реалізовано у середовищі Microsoft Excel. Визначено ступінь впливу напруженості магнітного поля на процес гідратації. Враховано залежить коефіцієнту масопередачі від зміни температури. 3 отриманого рівняння в числах подібності розраховано ряд теоретичних значень числа Стантона та порівняно з експериментальними даними.

Визначено розбіжність між розрахунковими та експериментальними даними в межах 18\%. Отримане рівняння дає змогу розраховувати об 'єм установки та швидкість протікання прочесу, задаючись різними режимними параметрами: напруженістю магнітного поля, температурою.

Ключові слова: гідратація, електромагнітне поле, температура, олія.

Вступ. Вкрай бажано вживати в їжу, з фізіологічної точки зору, олії з максимальним вмістом фосфоліпідів. Здійснити практично це не вдається, тому що фосфоліпіди, які легко розчиняються в оліях при температуpax їх одержання, надалі мимовільно з них виділяються при охолодженні. За рахунок протікання інтенсивних окисних, ферментативних і гідролітичних процесів утворюється осад, що швидко псується. У процесі виробництва і переробки соняшникової олії, враховуючи це, як правило, ії піддають частковій або повній рафінації. [1].

Актуальність. У мережах суспільного і дієтичного харчування збільшується зріст споживчого попиту на рослинні олії у фасованому або нефасованому вигляді, у тому числі для домашньої кулінарії. Однією із самих актуальних задач в умовах ринкової економіки, залишається підвищення конкурентоздатності вітчизняних видів рослинних олій та їх якості, а також досягнення високої стабільності та підвищеної біологічної цінності, які не втрачаються у процесі тривалого зберігання [2].

Аналіз літературних джерел. Літературний огляд показав, що ряд вчених розглядали питання вивчення впливу різного роду фізичних полів при очистці рослинних олій, до них відносяться наступні роботи, які проаналізовані нижче. Вивчаючи наукові праці Elena Roselló-Sotoa та J.Barbaa [3, 4] - де розглядається нове поняття вилучення супутніх домішок з сообстоків і побічних продуктів, які отримуються в процесі виробництва оливкової олії. Наведено вилучення поліфенолів, жирних кислот, барвистих пігментів та інших елементів за допомогою використання електромагнітних імпульсів. Нажаль у даному випадку застосування електромагнітного поля не використовується для очистки готового продукту. Натомість у наукових працях Isabel Odriozola-Serrano [5] наведені експериментальні досліди, за допомогою яких, виявили позитивний вплив імпульсних електричних полів для різних технологічних процесів у харчовій промисловості. Основна увага приділена тому що, ці технології є цінним інструментом, за допомогою яких може поліпшитись функціональність, екстрагуємість і вивільнення цінних харчових речовин, а також стають біодоступними мікроелементи і компоненти в різноманітних харчових продуктах. Тим паче, зважаючи увагу на те, що встановлено позитивний ефект від використання електромагнітних інтенсифікаторів, у науковій праці не наводиться застосування цих полів при очистці рослинних олій. Вивчаючи роботу Mahnič-Kalamiza S [6], бачимо, що в ній представлено перевагу використання електромагнітних полів над технологіями з термічними інтенсифікаторами, які стандартно використовуються при обробці харчових продуктів рідинного походження. Основ- 
ні результати були узагальнені, та висвітлені у рамках інтегрованого проекту FP6 СC «NovelQ», він висвітлює вплив електромагнітних полів на основні складових, які впливають на властивості речовин, регламентуючі якість продукції. Не зважаючи на це, досліди наведено для не в'язких рідин, якими не $\epsilon$ рослинні олії. Розглядаючи роботу А. A. Netreba [7], де представлено явище електропорації, яке було отримано за допомогою використання імпульсних електричних полів при впливі на харчові тканини, це призводило до покращення зв'язків між внутрішніми та зовнішніми клітинами за допомогою вмісту їх оболонки, що дозволило інтенсифікувати процес утворення коагуляції. Ці досліди проводились не для видалення супутніх речовин 3 олії, а з метою прискорення процесу льодоутворення. Спираючись на вивчені наукові дослідження можна припустити, що використання електромагнітного поля дозволить спостерігати інтенсифікацію процесу коагуляції при видалені фосфоліпідів з олій рослинного походження.

Мета досліджень. За допомогою теорії подібності отримати крітеріальне рівняння для узагальнення результатів експериментальних досліджень і провести порівняння отриманих експериментальних даних та теоретичних розрахунків процесу видалення фосфоліпідів 3 рослинних олій.

Результати досліджень. Гідратація - це додавання у олії води чи слабкого соленого розчину з нагрівом до $55-60{ }^{\circ} \mathrm{C}$. За допомогою гідратації речовини які утримують фосфор коагулюють і можуть бути видалені.

Розглянемо процес гідратації як стаціонарний масообмінний (рис. 1).

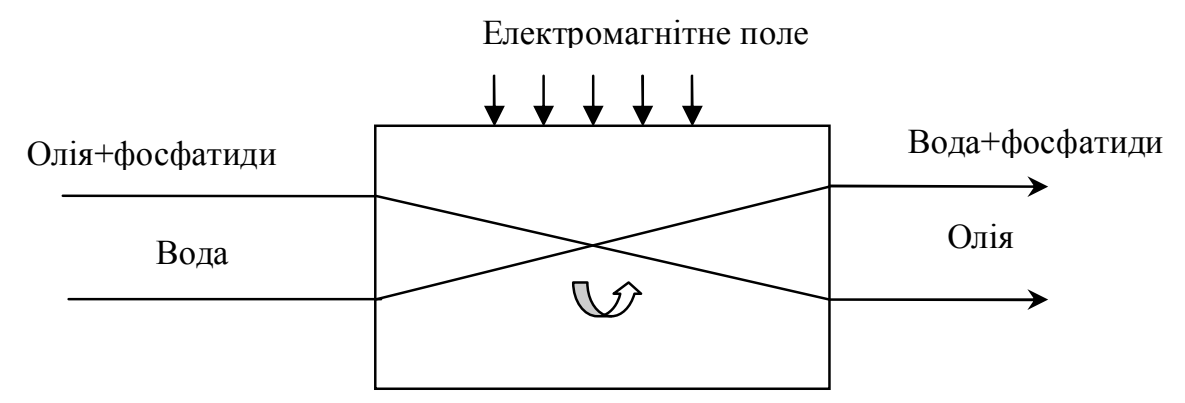

\section{Рис. 1 - Фізична схема процесу гідратації при обробці електромагнітними хвилями}

При змішуванні води з олією, мікропластівці зчіплюються, захоплюючи домішки і воду, і утворюють коагуляційну структуру у вигляді великих пластівців.

Основним показником такого процесу буде деякий об'ємний коефіцієнт масопередачі:

$$
K_{V}=\frac{M}{V \cdot a \cdot \Delta C}
$$

Де, V - об’єм апарату; а - питома поверхня контакту фаз (м/м³); $\Delta \mathrm{C}$ - різниця концентрації.

Основними факторами, що впливають на процес є: температура; величина дози коагулянту (води), швидкість його змішування і рівномірність розподілу в олії; умови протікання процесу утворення пластівців (вплив електромагнітного поля).

У цьому випадку надійним способом одержання структур критериальных рівнянь $є$ метод аналізу розмірностей. На основі його загальних принципів установлюємо вид критеріального рівняння для розрахунку продуктивності установки.

Коефіцієнт масопередачі, в такому випадку, залежить від наступних параметрів: напруженості магнітного поля (Н), температури (Т), швидкості потоку (U).

Використовуючи метод аналізу розмірностей, отримуємо рівняння виду:

$$
S t=A \cdot H^{k 1} \cdot \theta^{k 2}
$$

Де, $\mathrm{St}=\mathrm{K}_{\mathrm{v}} / \mathrm{v}$ - число Стантона; $\mathrm{v}$ - швидкість потоку; $\mathrm{H}=\mathrm{H}_{\tau} / \mathrm{H}_{0}$ - симплекс напруженості електромагнітного поля; $\mathrm{H}_{\tau}$ - поточне значення напруженості електромагнітного поля; $\mathrm{H}_{0}$ - початкове значення напруженості електромагнітного поля; $\theta=\theta_{\tau} / \theta_{0}-$ симплекс температури; $\theta_{\tau}$ - поточне значення температури олії; $\theta_{0}$ початкове значення температури олії; $\mathrm{A}, \mathrm{k}_{1}, \mathrm{k}_{2}$ - константи.

Вихідні дані для обробки отримані в результаті експериментальних досліджень. Також використані деякі табличні значення - теплофізичні властивості олії. Алгоритм (рис. 2) реалізовано в середовищі Microsoft Excel. Використовуючи функції Microsoft Excel, одержуємо показники ступеня в рівнянні в числах подібності. 


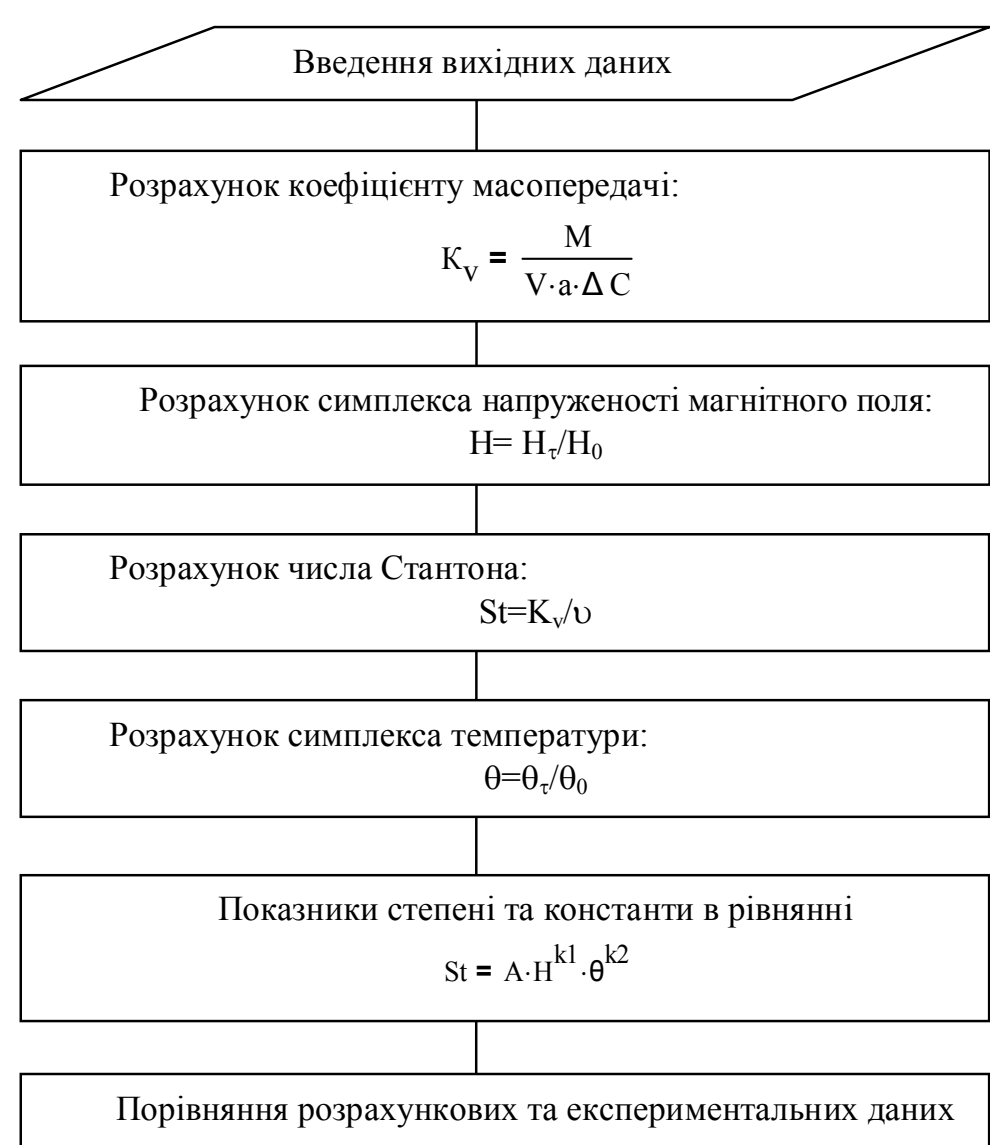

Рис. 2 - Алгоритм узагальнення експериментальних даних при зміні напруженості магнітного поля

Завдання узагальнення даних - отримати показники степені та константи в рівнянні (2).

Необхідно врахувати, як залежить коефіцієнт масопередачі від зміни температури. Будуємо залежність $\mathrm{St}=f(\theta)$ у логарифмічних координатах (рис. 3).

Криві розшаровуються залежно значення симплекса напруженості магнітного поля $\mathrm{H}_{\tau} / \mathrm{H}_{0}$. Тангенс кута нахилу прямих дорівнює 0,8 , що є показником ступеня у числа $\theta$.

Далі необхідно визначити ступінь впливу напруженості магнітного поля на процес. Будуємо залежність $\mathrm{H}_{\tau} / \mathrm{H}_{0}=f\left(\mathrm{St} / \theta^{0.8}\right)$ у напівлогарифмічних координатах. Тангенс кута нахилу кривих (рис. 4) дорівнює 1,8, що $\epsilon$ показником ступеня у числа $\mathrm{H}_{\tau} / \mathrm{H}_{0}$.

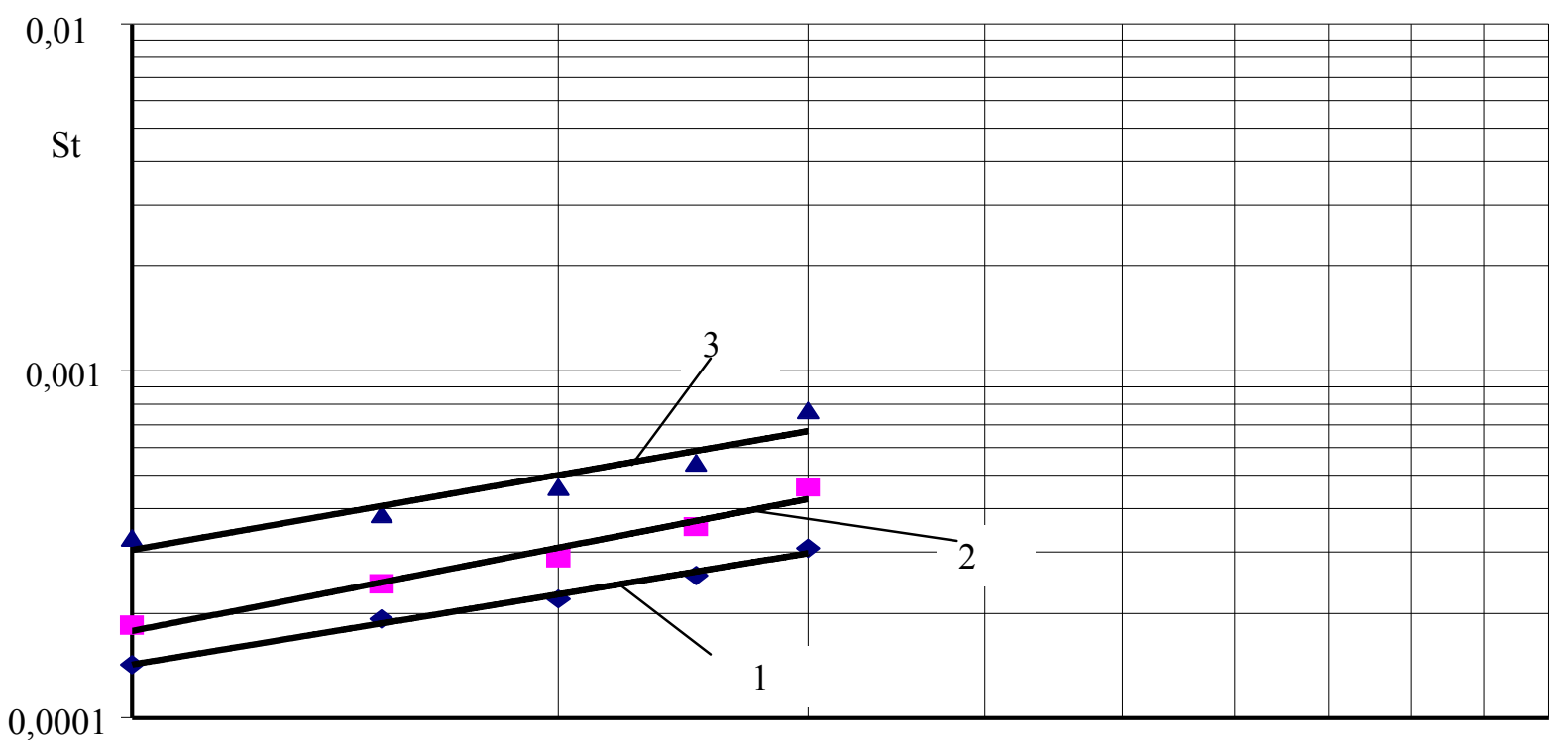

Рис. 3 - Залежність $\mathrm{St}=f(\theta)$ при значеннях $\mathrm{H}_{\tau} / \mathrm{H}_{0}: 1-1 ; 2-1,35 ; 3-1,52$ 


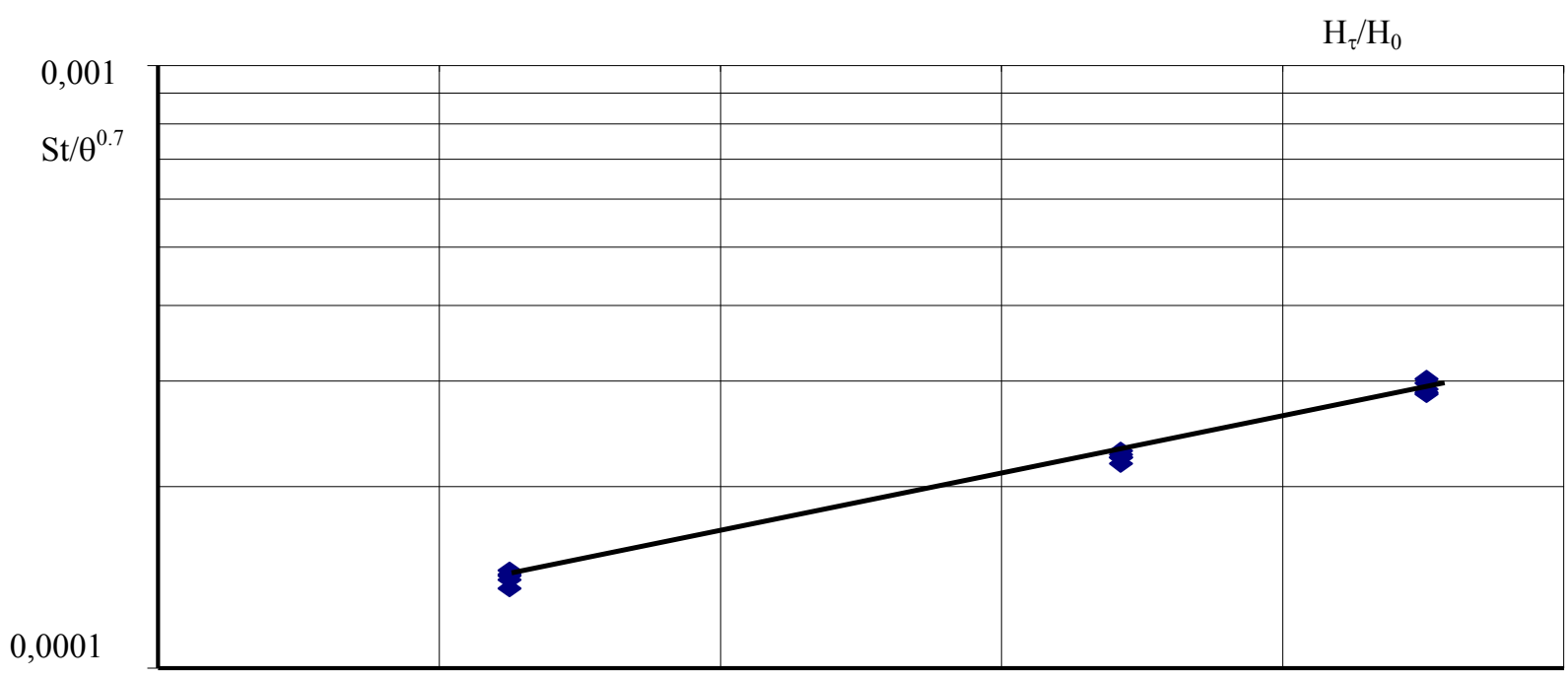

Рис. 4 - Залежність $\mathrm{H}_{\tau} / \mathrm{H}_{0}=f\left(\mathrm{St} / \theta^{0.8}\right)$

Остаточний результат обробки - рівняння виду:

$$
S t_{p}=0.0001 \cdot H^{1.8} \cdot \theta^{0.8}
$$

Використовуємо отримане рівняння в числах подібності для розрахунку ряду значень $\mathrm{St}_{\mathrm{p}}$. Порівнюємо 3 експериментальними даними (рис. 5). Для порівняння використовуємо отримані експериментальні дані [9]. Розбіжність в межах $18 \%$. Отримана модель із високою точністю описує отримані експериментальні дані.

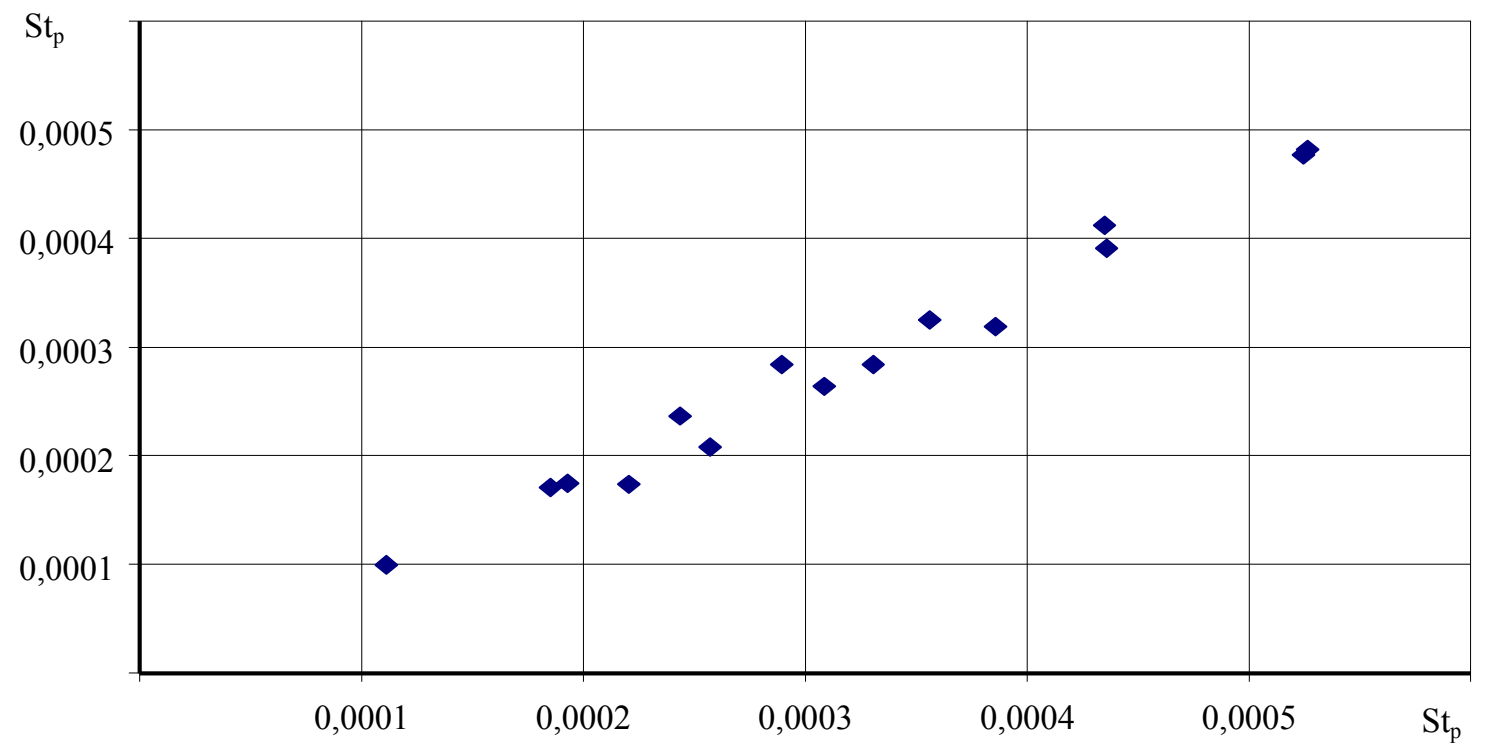

\section{Рис. 5 - Порівняння значень $\mathrm{St}_{\mathrm{p}}$ i експериментальних $\mathrm{St}$}

Використовуючи рівняння (3), зможемо розраховувати об’єм установки, швидкість процесу, задаючись різними режимними параметрами: напруженістю магнітного поля, температурою.

\section{Висновки}

Проведене моделювання процесу гідратації із застосуванням електромагнітних коливань показало, що визначальний вплив на процес надає зміна температури та напруженість електромагнітного поля. Це підтверджує і аналіз отриманої моделі (3). Показник ступеня при симплексі $\mathrm{H}_{\tau} / \mathrm{H}_{0}$ дорівнює 1,8 . Нижчий вплив на процес має температура продукту показник ступеня при симплексі $\theta$ дорівнює 0,8 . 


\title{
References
}

1. Harutyunyan, N.S., Kornena, E.P., Nesterova, E.A. (2004). Rafinatsiya masel i zhirov. Teoreticheskiye osnovy, praktika, tekhnologiya, oborudovaniye [Refining oils and fats. Theoretical foundations, practice, technology, equipment]. SPb .: GIORD (in Russian).

2. Harutyunyan N.S, Kornena E.P. (1986). Fosfolipidy rastitel'nykh masel [Phospholipids of vegetable oils]. M.: Agropromizdat (in Russian).

3. Elena Roselló-Sotoa, Mohamed Koubaab, Amine Moubarikc, Rita P. Lopesd, Jorge A. Saraivad, Nadia Boussettab, Nabil Grimib, Francisco J. Barbaa. (2016). Emerging opportunities for the effective valorization of wastes and by-products generated during olive oil production process: Non-conventional methods for the recovery of high-added value compounds. Trends in Food Science \& Technology, 45( 2), 296-310.

4. Francisco J.Barbaa, Oleksii Parniakovb, Sofia A. Pereirac, Artur Wiktord, Nabil Grimib, Nadia Boussettab, Jorge A. Saraivac, Javier Rasoe, Olga Martin-Bellosof, Dorota Witrowa-Rajchertd, Nikolai Lebovkabg, Eugène Vorobievb. (2016). Current applications and new opportunities for the use of pulsed electric fields in food science and industry. Food Research International, 77( 4), 773-798

5. Isabel Odriozola-Serrano, Ingrid Aguiló-Aguayo, Robert Soliva-Fortuny, Olga Martín-Belloso. (2015) Pulsed electric fields processing effects on quality and health-related constituents of plant-based foods. // Trends in Food Science \& Technology. Volume 29, Issue 2, 98-107

6. Mahnič-Kalamiza S, Vorobiev E, Miklavčič D. (2016). Electroporation in food processing and biorefinery. The Journal of Membrane Biology, 247(12), 1279-1304

7. Netreba,A. A., Gladky, F. F., Sadovnichy, G. V., Shkalyar, T. G. (2017). Ispol'zovaniye elektromagnitnogo polya $\mathrm{v}$ protsesse vymorazhivaniya podsolnechnogo masla [The use of the electromagnetic field in the process of freezing sunflower oil]. Visnyk Natsional'noho tekhnichnoho universytetu KhPI. Seriya: Innovatsiyni doslidzhennya u naukovykh robotakh studentiv, (49), 3-14.

8. Osadchuk, P. I., Domuschi, D. P., Enakiev, Y. I., Peretiaka, S. N., Lipin, A. P. (2020). Study of the effect of ultrasonic field in purifying sunflower oil. Bulgarian Journal of Agricultural Science, 26 (2) , 486-491

9. Osadchuk P.I. (2019). Vykorystannya elektromahnitnoho polya pry hidratatsiyi roslynnykh oliy [Use of electromagnetic field in hydration of vegetable oils]. Scientific Works, 83(1), 98-103 (in Ukrainian).

\section{ENGINEERING METHODS OF CALCULATION OF THE HYDRATION PROCESS DURING OIL TREATMENT BY ELECTROMAGNETIC WAVES}

\author{
${ }^{1}$ Osadchuk P. I., doctor of technical sciences, associate professor, \\ ${ }^{2}$ Bezbakh I. V., doctor of technical sciences, associate professor \\ ${ }^{1}$ Odessa State Agrarian University, m. Odessa \\ ${ }^{2}$ Odessa National Academy of Food Technologies
}

The concept of optimal nutrition, which underlies modern ideas about nutrition and health, requires a new approach to the composition and properties of food, which should not only meet the needs of the human body in nutrients and energy, but also provide it with the full range of necessary macro - and micronutrients, contributing to the prevention of food-dependent diseases, maintaining health and longevity. Modern requirements of nutrition science have led to the emergence of new groups of products with new composition and properties. These changes are associated with an understanding of the role of nutrition in human life, the relationship between food quality and disease of civilization, as well as new working conditions and changes in the rhythm of life, the growth of environmental problems. The main disadvantages of standard hydration lines include high energy consumption, high consumption of cold water and steam, which is associated with the use of separators, as well as harsh temperature drying conditions of the phospholipid emulsion. These lines do not ensure the efficiency of the process as a whole due to the high residual content of phospholipids in the oil and the low nutritional value of the obtained phosphatide concentrates due to the influence of hydrogen peroxide used for decolorization. To eliminate these shortcomings, it was proposed to use electromagnetic fields in the process of hydration of oils. In this paper, engineering methods for calculating the hydration process during oil treatment by electromagnetic waves are proposed. The process is modeled. Using the method of dimensional analysis, a criterion equation for calculating the performance of the equipment is obtained. The generalization of experimental data obtained as a result of research is carried out. An algorithm for calculating power indicators and constants in the equation in similarity numbers has been developed and implemented in the Microsoft Excel environment. The degree of influence of the magnetic field strength on the hydration process is determined. The mass transfer coefficient depends on the temperature change. From the obtained equation in the similarity numbers a number of theoretical values of Stanton are calculated and compared with experimental data. The discrepancy between the calculated and experimental data within 18\% was determined. The result- 
ing equation allows you to calculate the volume of the installation, the speed of the process, given the various mode parameters: magnetic field strength, temperature.

Keywords: hydration, electromagnetic field, temperature, oil.

\section{Список використаної літератури}

1. Арутюнян Н.С., Корнена Е.П, Нестерова Е.А. Рафинащия масел и жиров. Теоретические основы, практика, технология, оборудование. СПб.: ГИОРД, 2004. 288 с.

2. Арутюнян Н. С., Корнена Е. П. Фосфолипиды растительных масел. М. Агропромиздат, 1986. 415 c.

3. Elena Roselló-Sotoa et al. Emerging opportunities for the effective valorization of wastes and by-products generated during olive oil production process: Non-conventional methods for the recovery of high-added value compounds. Trends in Food Science \& Technology. 2016. Volume 45, Issue 2. P. 296-310

4. Francisco J.Barbaa et al. Current applications and new opportunities for the use of pulsed electric fields in food science and industry. Food Research International. 2016. Volume 77. Part 4. P. 773-798

5. Odriozola-Serrano I., Aguiló-Aguayo I., Soliva-Fortuny R., Martín-Belloso O. Pulsed electric fields processing effects on quality and health-related constituents of plant-based foods. Trends in Food Science \& Technology. 2015. Volume 29, Issue 2. P. 98-107

6. Mahnič-Kalamiza S, Vorobiev E, Miklavčič D. Electroporation in food processing and biorefinery. The Journal of Membrane Biology. 2016. 247(12). P. 1279-1304

7. A. A. Netreba, F. F. Gladky, G. V. Sadovnichy, T. G. Shkalyar. The use of the electromagnetic field in the process of freezing sunflower oil Herald Nat. tech. Un-that "KPI": Sat. scientific tr. Theme Vol .: Innovative research in the scientific works of students. - Kharkov: NTU "KhPI", 2014. 49 (1091). P. 3-14.

8. Osadchuk P. I. et. al. Study of the effect of ultrasonic field in purifying sunflower oil. Bulgarian Journal of Agricultural Science, 2020. Vol. 26. No 2. P. 486-491.

9. Осадчук П. І. Використання електромагнітного поля при гідратації рослинних олій. Наукові праці, 2019. Випуск 1(83). С. 98-103. 